\title{
Effects of a health promotion and fall prevention program in elderly individuals participating in interaction groups
}

\author{
Efeitos de um programa de prevenção de quedas em \\ idosos participantes de grupos de convivência
}

\author{
Lays Cavallero Pagliosa ${ }^{[a]}$, Alexandra Renosto ${ }^{[b]}$ \\ [a] Graduate in Physical therapy at the Serra Gaúcha College (FSG), Caxias do Sul, RS - Brazil, e-mail: \\ layscavallero@hotmail.com \\ [b] Master's degree in Public Health, professor at the Serra Gaúcha College (FSG), Caxias do Sul, RS - Brazil, e-mail: \\ alexandra.renosto@fsg.br
}

\begin{abstract}
Introduction: Falls in elderly people are an increasing public health problem resulting in high costs to health services. Thus, it is essential to invest in the development of actions and programs focused on decreasing such risks. Objective: To verify the effects of a program of health promotion and prevention of falls in relation to balance and functional abilities in elderly people participating in interaction groups in Caxias do Sul City, RS State. Materials and methods: For this purpose, 14 elderly people were selected for assessment and reassessment through the following instruments: the Barthel Index, Timed Up and Go Test (TUG), Berg Balance Scale (BBS), and a questionnaire to characterize the sample. Over the course of 2 months, group activities were conducted in a multi-sensory and proprioceptive circuit with a frequency of 2 times per week, totaling 14 meetings. Results: The average age of participants was about 72 years old, mostly women (78.6\%); $64.3 \%$ of them had experienced falls, and $92.9 \%$ had already practiced physical activities. After the intervention, there was an average increase of 9.14 points in the BBS $(\mathrm{p}=0.000)$ and an average reduction of 4.4 seconds in gait speed on the TUG test $(p=0.000)$. Conclusion: The application of the proposed program resulted in increasing balance and gait performance of the elderly, reducing the risk of falls.
\end{abstract}

Keywords: Health of the elderly. Accidental falls. Health promotion. Primary prevention.

Interaction and leisure centers. 


\section{Resumo}

Introdução: As quedas em idosos são um problema de saúde pública crescente, gerando custos elevados aos serviços de saúde. Dessa forma, é essencial investir na criação de ações e programas que priorizem a diminuição destes riscos. Objetivo: Verificar os efeitos de um programa de promoção da saúde e prevenção de quedas em relação ao equilíbrio e capacidade funcional em idosos participantes de grupos de convivência do município de Caxias do Sul (RS). Materiais e métodos: Foram sujeitos 14 idosos avaliados e reavaliados pelos seguintes instrumentos: Índice de Barthel, Teste Timed Up and Go (TUG), Escala de Equilíbrio de Berg (EEB), e um questionário para a caracterização da amostra. Durante 2 meses foram realizadas atividades em grupo em um circuito multissensorial e proprioceptivo, com frequência de 2 vezes por semana, totalizando 14 encontros. Resultados: A média de idade dos participantes foi de 72 anos, a maioria do sexo feminino (78,6\%), sendo que $64,3 \%$ já haviam sofrido quedas e 92,9\% praticavam atividade física prévia. Após a intervenção, houve aumento médio de 9,14 pontos na EEB ( $p=0,000)$ e diminuição média de 4,4 segundos na velocidade da marcha no TUG ( $p=0,000)$. Conclusão: A aplicação do proposto programa incrementou o equilíbrio e o desempenho da marcha dos idosos, reduzindo o risco de ocorrência de quedas.

Palavras-chave: Saúde do idoso. Acidentes por quedas. Promoção da saúde. Prevenção primária. Centros de convivência e lazer.

\section{Introduction}

The elderly population is increasing all over the world but particularly in developing countries. According to the World Health Organization, in 2007 the number of elderly people around the world was about 650 million. In Brazil, according to data provided by IBGE, the number was nearly 21 million in 2010. In 2025, Brazil is expected rank $6^{\text {th }}$ in the world for the proportion of elderly to the total number of inhabitants in the country with around 35 million elderly. In 2050, this figure will have increased to 63 million $(1,2)$.

Aging causes several alterations in the human organism, modifying structures and functions, which results in high vulnerability to pathological processes and accidents. However, this is a personal and differentiated process depending on the genetics and lifestyle of each individual. This should occur healthily and with high quality of life in which functional abilities and autonomy are preserved $(3,4,5,6)$. However, longevity is not always accompanied by conditions that favor elderly people. In this case, the lack of suitable preparation for old age will certainly result in the propensity to falls (7).

Falls in elderly people are a yearly increasing public health problem both in Brazil and throughout the world. Their respective consequences may vary from minor injuries to severe pathologies, which reduce functional abilities, autonomy, and quality of life and may often cause death (8). In Brazil, 30\% of the elderly experience falls at least once a year. The incidence is higher in women than in men in the same age group. Among all these falls, 5\% result in fractures, and between $5 \%$ and $10 \%$ result in major injuries that require medical care (5).

Some falls may require hospitalization, and this will put the elderly in an immobility situation that may result in several health complications. According to a survey conducted by the Ministry of Health, the number of elderly hospitalized in public health services due to femoral fractures mainly caused by falls increased by $37 \%$ between 2000 and 2007. In addition to fractures, falls also trigger fear of further falls, abandonment of certain activities, changing habits, and immobilization $(7,9)$.

Falls result in high costs to health services in Brazil. Each year, the Unified Health System (SUS, as per its acronym in Portuguese) has increasing costs related to the treatment of fractures in elderly people. According to data provided by the Ministry of Health, in 2006, about $\mathrm{R} \$ 49$ million were spent on hospitalizations. In 2009, this figure had increased to R \$ 57.61 million (10). As stated by Neto (2009), “[...] with an increasing elderly population, governments tend to spend more on health services because this 
population is more susceptible to diseases. However, the primary investment should be on prevention aiming at avoiding later expenditures with treatments, hospitalizations and others" (11).

The role of physical therapy in the prevention of falls occurs through activities and exercises targeted to improve balance, motor coordination, proprioception, stability and postural control, gait, muscular strength, and flexibility and functionality. At the same time, this aims at avoiding immobility and its negative consequences. The guidelines related to extrinsic risk factors should also be provided by physical therapists (12).

Thus, the implementation of programs for prevention of falls is supposed to improve the balance and functionality and also reduce the risk of falls in elderly people of the community. Following a doubleblind study related to prevention of falls in the community, Steinberg et al. (13) concluded that over $80 \%$ of the elderly were more aware about risk factors and prevention and that they observed an increase in their functionality and welfare (13).

Pursuing a promotion and prevention approach concerning the functional health of the elderly in the community, this study aimed at verifying the effect of a health promotion and fall prevention program in relation to the balance and functional abilities of elderly people participating in interaction groups in Caxias do Sul City, RS State in order to develop subsidies for implementation of this model in other elderly interaction groups as well as in the Health Care Units.

\section{Materials and methods}

This research was characterized by a quantitative, quasi-experimental study. It targeted elderly people participating in interaction groups in Caxias do Sul City, RS State. The sample was recruited through nonprobability convenience. The elderly involved in this sample were participants of the SCAN's interaction group - Association for Helping the Needy of Caxias do Sul: Center and Interaction Groups for Elderly. Adults aged 60 years or over who were normotensive individuals and agreed on the proposed intervention and who had signed the Free and Informed Consent Form were included.

Adults under 60 years of age with cognitive and neurological deficits, clinical diagnosis of vestibular syndromes, impossibility of unassisted locomotion, physical disability to complete the proposed treatment, non-commitment towards the proposed interventions (more than two consecutive unjustified absences or non-attendance to at least $50 \%$ of the total meetings of the intervention) and who voluntarily waived participation in the research were excluded.

After approval by the FSG Research Ethics Committee (filed under number 0144/2011) and the people responsible for interaction groups' approval, a meeting was held with the SCAN's participants in order to explain the project, and the elderly interested in participating in the study were selected. Among this group, 24 individuals of both genders were selected and were effectively accepted as participants by signing the Free and Informed Consent Form. After that, the instruments for assessment were individually applied in one of the SCAN's rooms.

A questionnaire was used for sample characterization. In addition, there were three instruments employed for functionality, static, and dynamic balance assessment. All questioning related to falls and triggering factors of falls were adapted to the literature (14).

For functionality assessment, the Barthel Index was employed in order to verify the ability of completing basic activities in daily living. This index is commonly used in Brazil along with a translated version in bibliographical research (15). Scoring may vary from 0 to 100 , and an individual is classified as completely independent by achieving the maximum score and completely dependent by achieving the minimum score (16).

For the dynamic balance and risk of falling assessment, the Timed Up and Go Test (TUG) was employed aiming at quantifying the mobility performance through the speed reached during the task. For the test completion, the individual should stand up from a chair, walk in a straight line up to the location marked with an X (about three meters from the chair), turn around, walk back to the chair and sit down, returning to the original position. If the time taken for the task is up to 20 seconds, the individual is classified as completely independent for accomplishing basic activities of daily living. Increased risk of falling is considered when the time taken for task completion is over 20 seconds (17). As stated by Gonçalves et al. (18), 10 seconds is the period classified as normal for healthy and independent adults to complete the test with no risk of falls; from 11 to 20 seconds is the period expected for elderly people with impairments or who are frail, who are partially independent and 
with low risk of falls; over 20 seconds represents a significant deficit in physical mobility and risk of falls (18).

The balance was also assessed through the Berg Balance Scale (BBS). This test was accomplished according to the instructions provided in the Brazilian version (19). This version was approved and published by Miyamoto et al. (20) and is highly reliable. This scale aims at assessing the functional balance performance based on 14 ordinary items of daily living. The maximum achievable score is 56 points, and scoring lower than 45 points suggests balance alterations (20).

Afterwards, an intervention program was engaged in the headquarters of the interaction groups. This program was implemented for 2 months, occurring 2 days per week (totaling 14 meetings) and lasting 45 minutes per meeting. All proposed activities were accomplished in groups aiming at improving balance, motor coordination, proprioception, stability and postural control, corporal awareness, gait, muscular strength, and flexibility and at promoting social interaction. These objectives were worked out through warming up and a multi-sensory circuit that included kinesiotherapy and stretching exercises to close the meeting.

The circuit was mounted using contact paper, cones, balls, and chairs. It was divided into 12 stages:

1) walking forward and backward over a trace on the ground;

2) walking on a straight line moving the head sideways;

3) stepping sideways to the left and to the right;

4) gaiting only supported by the posterior third of the feet (forwards and backwards);

5) gaiting only supported by the anterior third of the feet (forwards and backwards);

6) stepping with one foot ahead of the other;

7) frontal gaiting with cross stepping and fully supported by the feet;

8) staying in unipodal support;

9) treading in areas with different colors following the numerical order;

10) gaiting on a circumferential path formed by cones;

11) sitting and rising from a chair while maintaining a ball wedged between the knees;

12) plant and dorsiflexion in orthostatic position supporting on a chair.
Once the intervention program was completed, the instruments for assessment were reapplied to the individuals participating in the research for later data analysis and outcomes interpretation.

Concerning statistical analysis, the SPSS statistics program, version 16.0 for Windows was used for the entry and analysis of data with the sample characteristics described by setting the average, minimum, maximum and absolute $(\mathrm{N})$ and relative $(\%)$ frequencies. Data normality was tested through histogram and Shapiro-Wilk test. By assuming data parameters, the paired Student's T-test was employed. The significance level was $\mathrm{p} \leq 0.05$.

\section{Results}

Among the elderly initially assessed $(n=24), 10$ were excluded because they did not attend at least $50 \%$ of the intervention ( 7 meetings). Therefore, the final sample was composed of 14 elderly people. Among these, the average age was 72 years old with a minimum age of 63 and a maximum of 84 years old. Other outcomes characterizing the sample are found in Table 1. Data related to the occurrence of falls are described in Table 2.

Regarding the instruments for assessment employed, the TUG test demonstrated the elderly achieving the initial average (pre-intervention) of $14 \mathrm{sec}-$ onds for completion of the test. The final average achieved (post-intervention) was 9.6 seconds, which resulted in a difference of 4.4 seconds between preand post-intervention, a highly significant outcome $(\mathrm{p}=0,000)$.

The use of BBS demonstrated that, initially, the average achieved by the elderly was 44.57 points. After the program implementation, the average achieved was 53.71 points, resulting in a difference of +9.14 points between pre- and post-intervention. The statistics analysis also demonstrated a highly significant outcome $(\mathrm{p}=0.000)$.

In the case of the Barthel Index, which verifies the functional ability related to basic activities of daily living, there was no significant difference between pre- and post-intervention, because the values found were exactly the same in both moments. Tables 3 and 4 demonstrate the average values related to the assessment instruments TUG and BBS used before and after the implementation of the proposed intervention. 
Table 1 - Demographic, social, and lifestyle characteristics of the elderly participating in interaction groups in Caxias do Sul City, RS State, 2011. ( $\mathrm{N}=14)$

\begin{tabular}{lcc}
\hline Variables & Categories & N (\%) \\
\hline \multirow{2}{*}{ Gender } & Female & $11(78.6 \%)$ \\
& Male & $3(21.4 \%)$ \\
Participation on SCAN & $1-2$ years & $6(42.9 \%)$ \\
& $3-5$ years & $5(35.7 \%)$ \\
Physical Activity & +5 years & $3(21.4 \%)$ \\
& Practices & $13(92.9 \%)$ \\
\hline
\end{tabular}

Source: Research data.

Table 2 - Variables to the occurrence of falls in elderly participating in interaction groups in Caxias do Sul City, RS State, 2011. $(\mathrm{N}=14)$

\begin{tabular}{lcc}
\hline Variables & Categories & N (\%) \\
\hline \multirow{2}{*}{ Occurrence of falls } & Present & $9(64.3 \%)$ \\
\multirow{2}{*}{ Number of falls } & Absent & $5(35.7 \%)$ \\
& 1 time & $1(11.2 \%)$ \\
\hline
\end{tabular}

Source: Research data.

Table 3 - Outcomes of TUG test related to pre- and post-intervention in elderly participating in interaction groups in Caxias do Sul City, RS State, 2011

\begin{tabular}{|c|c|c|c|}
\hline $\begin{array}{c}\text { TUG } \\
\text { Pre-Intervention }\end{array}$ & $\begin{array}{c}\text { TUG } \\
\text { Post-Intervention }\end{array}$ & $\begin{array}{l}\text { Difference Pre and } \\
\text { Post-Intervention }\end{array}$ & $\mathrm{p}$-value \\
\hline 14 seconds & 9.6 seconds & -4.4 seconds & $0.000^{*}$ \\
\hline
\end{tabular}

Note: *: p-value $\leq 0.05$.

Source: Research data.

Table 4 - Outcomes of BBS related to pre- and post-intervention in elderly participating in interaction groups in Caxias do Sul City, RS State, 2011

\begin{tabular}{cccc}
\hline $\begin{array}{c}\text { BBS } \\
\text { Pre-Intervention }\end{array}$ & $\begin{array}{c}\text { BBS } \\
\text { Post-Intervention }\end{array}$ & $\begin{array}{c}\text { Difference Pre and } \\
\text { Post-Intervention }\end{array}$ & p-value \\
\hline 44.57 points & 53.71 points & +9.14 points & $0.000^{*}$ \\
\hline
\end{tabular}

Note: *: p-value $\leq 0.05$.

Source: Research data. 


\section{Discussion}

A longer life should be accompanied by continuous opportunities for health, participation and security (21). According to Borges et al. (22), maintaining the elderly of the community in an active aging situation is essential to reduce investments in secondary and tertiary preventions, treatment, rehabilitation and institutionalization. The interaction groups become strategic options for promoting active aging in order to provide the accomplishment of varied activities related to recreational, cultural, social, and educational, and health promotion interests (22).

By characterizing the sample, greater participation was observed in elderly women. As stated by Gomes et al. (22), public services for health promotion are frequented mainly by women, and the professional staff is composed mostly of women. Such situations may cause men to feel that they do not belong to that space, and, consequently, they do not recognize themselves as a target of the care provided by health programs (23).

Concerning physical activities, data demonstrated that almost all elderly of the sample analyzed used to practice exercises especially when they were at the headquarters of the interaction groups. Such data confirm the studies conducted by Mazo et al. (24), Matsudo et al. (25), Conte and Lopez (26) and Cardoso et al. (27), which showed a higher level of physical activity among the participants of interaction groups as compared to elderly in the overall population $(24,25,26,27)$. At the institution where the present study was implemented, physical activities are optional, performed three times per week and include dancing, walking, gymnastics, stretching exercises and muscles strengthening.

Regarding the intervention program, it was decided to exclude the elderly who did not attend to at least $50 \%$ of the program activities. This is because consistent absence during the intervention period could result in not achieving the expected outcomes. According to Kisner and Colby (12), continually performing the proposed exercises is required for the maintenance of morphophysiological adaptations and the permanence of physical and functional acquisitions possibly developed by training (12).

About the variable functionality, the scoring achieved in the Barthel Index during the pre-intervention period varied from 95 to 100 points, meaning between mild dependence and functional independence. The decisive factor for mild dependence classification was the item related to urinary incontinence in which a number of elderly reported occasional accidents of urinary loss. After the implementation of the health promotion and fall prevention programs, the scoring achieved through this index was exactly the same for all the elderly of the sample without statistical significance between these two moments.

One of the possible explanations for the high scoring achieved in this index was the regular practice of physical activities and the accomplishment of domestic chores. Other explanations are related to the fact that the elderly live alone and move around up to the institution either by public transport or ambulation. As stated by Dipietro (28), individuals who practice high levels of physical activities present lower functional loss (about 50 and 60\%) than those who practice low levels of physical activities (28).

According to Borges et al. (22), functional ability determines how much people can live independently within the family and community contexts, and this fact influences, for example, their capacity to participate in events and use the services provided by social organizations (22). In the case of the elderly involved in this study and who participate in different social and cultural activities, this outcome was somewhat expected.

With regard to the TUG test, at the pre-intervention period, the average value achieved was 14 seconds for test accomplishment. Therefore, the elderly were already at low risk for falls. After two months of intervention, there was a statistically significant reduction in the time for test accomplishment, representing an improvement in performance, speed, and balance while gaiting.

A possible explanation for the low average time initially presented for test accomplishment may be that these were very active elderly. A study conducted by Guimarães et al. (29), in which they applied the same test for assessing the functional mobility of 20 elderly who used to practice physical activities and 20 sedentary elderly, it was concluded that the elderly who used to practice physical activities took less time for test accomplishment than the sedentary elderly (29).

In a study conducted by Ribeiro et al (30), which aimed at comparing the balance among not trained and trained elderly (within the last 12 months before the study, with 1 hour session at least 3 times 
per week), with the total of 144 elderly participating, and using the TUG test, it was concluded that trained elderly presented a better functional mobility performance as compared to not trained elderly $(13.0 \mathrm{~s} \pm$ $4.2 \mathrm{~s} v s .17 .6 \mathrm{~s} \pm 7.5 \mathrm{~s})(30)$.

Zambaldi et al. (31) conducted balance training with a group of six elderly women of the community for one hour two times per week for eight weeks. The minimum and maximum values found through the TUG test before the intervention were 10 and 60 seconds, respectively, and after the intervention they were 9 and 45 seconds, respectively, which demonstrates an improvement in balance and functional mobility after the intervention (31). In the study conducted by Nitz and Choy (32) with 73 elderly, the outcomes achieved post-training highlighted a reduced time for TUG test accomplishment (32).

Concerning the BBS, the score initially achieved was 44.57 points, suggesting a balance deficit and risk of falls. A significant increase in post-intervention scores was observed, achieving 9.14 points. These data confirm the study conducted in São Paulo by Soares and Sacchelli (33) with a sample of 40 elderly with an average age of 71 years old in which they employed a therapy protocol 2 times per week for 60 minutes each over 12 weeks, which contained warmup activities, stretching and muscles strengthening exercises, balance training, and muscular relaxation. The outcomes demonstrated an initial average of 51 points and a final average of 54 points, meaning that statistical significance was found (33).

Likewise, after the intervention proposed by Zambaldi et al. (31), the BBS's minimum and maximum values before the intervention were 34 and 50 , respectively, and after the intervention they were 42 and 54, respectively, which suggests an improvement in the functional balance of the elderly (31). Wolf et al. (34) achieved an improvement in the BBS' scoring in about $60 \%$ of the participants after the sensorialmotor training (34). Nascimento et al. (35) analyzed the effect of a four-week proprioceptive training program (2 times per week, 20-minute sessions) on postural balance measurements of nine elderly people, and they achieved an improvement in BBS's scoring in the post-intervention period (from $50.8 \pm 2.4$ to $53.6 \pm 1.5$ ) (35).

Finally, it is highlighted that the proposed program implementation occurred through a multi-sensory and proprioceptive circuit, recreationally performed in groups, aiming at providing an interaction environment during the activities related to preventive interests.

\section{Conclusion}

This study shows that, through an intervention in groups containing a multi-sensory and proprioceptive circuit, the functional balance and gaiting performance in elderly can be improved. However, it is important to consider that the occurrence of falls is an event involving several factors and, therefore, it is not possible to confirm the reduction in the occurrence of falls. It can only be concluded that, considering the aspects analyzed in this study, the prevention of falls was effectively implemented.

Some limitations found in this study were the method employed for sample recruitment (nonprobability convenience) and the reduced size of the sample. Therefore, the outcomes may contain biases and uncertainties that reduce the statistical power of this study and set limits to generalizing the outcomes achieved. Although we attempted to recruit all elderly registered in the interaction groups in which the study was conducted, this was impossible because a number of elderly did not attend often enough. As the study was conducted during the winter, some unexpected situations may have occurred (illnesses related to respiratory problems and reduced number of elderly present at the group in the coldest days, among others) with the sample selected and initially assessed, reducing the number of reassessed elderly and, consequently, the final sample total.

The activities proposed in the circuit were mostly multi-sensory and proprioceptive, only containing two exercises particularly targeted to muscle strengthening: sit down and stand up, ankle plant, and dorsiflexion in orthostatic position. It would be interesting to verify the effects of the implementation of similar programs but particularly targeted to muscles strengthening, which is also related to balance maintenance. Another suggestion is conducting new experimental research from the clinical trial type involving a more significant sample and a longer duration. It is also convenient to use the most beneficial exercise types both in short and long terms.

The outcomes achieved may contribute to further studies and to develop subsidies for the implementation of similar programs in other interaction groups 
and at the Health Care Units in an attempt to promote their members' health and reduce costs in secondary and tertiary preventions, treatment, rehabilitation, and possible institutionalization of the elderly.

\section{References}

1. World Health Organization. 10 facts on ageing and the life course. 2012 [cited 2010 Dec 20]. Available from: http://www.who.int/features/factfiles/ageing/ en/index.html

2. Instituto Brasileiro de Geografia e Estatística - IBGE. Censo Demográfico 2000. Brasília: IBGE; 2001.

3. Rebelatto JR, Morelli JGS. Fisioterapia geriátrica: a prática da assistência ao idoso. Barueri: Manole; 2004.

4. Netto FLM. Aspectos biológicos e fisiológicos do envelhecimento humano e suas implicações na saúde do idoso. Rev Pensar a Prática. 2004;7(1):75-84.

5. Dziedzinski AT. Fatores indicativos de risco de quedas em pacientes idosos com demência irreversível [dissertação]. Porto Alegre: Pontifícia Universidade Católica do Rio Grande do Sul; 2009.

6. Ministério da Saúde (Brasil). Secretaria de Atenção à Saúde. Envelhecimento e saúde da pessoa idosa. Brasília, 2006 [cited 2011 Nov 14]. Available from: http://189.28.128.100/dab/docs/publicacoes/cadernos_ab/abcad19.pdf

7. Ribeiro AP, Souza ER, Atie S, Souza AC, Schilithz AO. A influência das quedas na qualidade de vida dos idosos. Ciênc saúde colet. 2008;13(4):1265-73.

8. Gonçalves LG, Vieira ST, Siqueira FV, Hallal PC. Prevalência de quedas em idosos asilados do município de Rio Grande, RS. Rev Saúde Pública. 2008; 42(5):938-45.

9. Freitas MPD. Promoção da saúde e sistema de vigilância das DANT: traçando caminhos para o envelhecimento ativo e saudável. Brasília: Ministério da Saúde; Secretaria de Vigilância em Saúde; 2006.

10. Ministério da Saúde (Brasil) [homepage]. Brasília; 2009 [cited 2010 Nov 8]. SUS gasta quase R 81 milhões com fraturas em idosos em 2009. Available from: http://portal.saude.gov.br/portal/saude/visualizar_ texto.cfm?idtxt=33674\&janela $=1$
11. Duncan LGW Neto. Os benefícios do treinamento de força no processo de envelhecimento: estudo de revisão de artigos científicos [dissertação]. Porto Alegre: Pontifícia Universidade Católica do Rio Grande do Sul; 2009.

12. Kisner C, Colby LA. Exercícios terapêuticos: fundamentos e técnicas. 5. ed. Barueri: Manole; 2009.

13. Steinberg M, Cartwright C, Peel N, Williams G. A sustainable programme to prevent falls and near falls in community dwelling older people: results of a randomised trial. J Epidemiol Community Health. 2000;54(3):227-32.

14. Lopes MCL, Violin MR, Lavagnoli AP, Marcon SS. Fatores desencadeantes de quedas no domicílio em uma comunidade de idosos. Cogitare Enferm. 2007; 12(4):472-7.

15. Renosto A, Trindade JLA. A utilização de informantes-chave da comunidade na identificação de pessoas portadoras de alterações cinético-funcionais da cidade de Caxias do Sul, RS. Ciênc saúde coletiva. 2007;12(3):709-16.

16. Araújo F, Ribeiro JLP, Oliveira A, Pinto C. Validação do Índice de Barthel numa amostra de idosos não institucionalizados. Rev Port Sau Pub. 2007;25(2):59-66.

17. Rodriguez V. 0 teste timed up and go como predutor de quedas em idosos acima de 50 anos [monografia]. Cascavel: Faculdade Assis Gurgacz; 2006.

18. Gonçalves DFF, Ricci NA, Coimbra AMV. Equilíbrio funcional de idosas da comunidade: comparação em relação ao histórico de quedas. Rev Bras Fisioter. 2009;13(4):316-23.

19. Soares KV, Figueiredo KMOB, Caldas VVA, Guerra RO. Avaliação quanto à utilização e confiabilidade de instrumentos de medida do equilíbrio corporal em idosos. PubliCa. 2005;1:78-85.

20. Miyamoto ST, Lombardi I Jr., Berg KO, Ramos LR, Natour J. Brazilian version of the Berg balance scale. Braz J Med Biol Res. 2004;37(9):1411-21.

21. World Health Organization. Envelhecimento ativo: uma política de saúde. Brasília: Organização PanAmericana da Saúde; 2005. 
22. Borges PLC, Bretas PR, de Azevedo SF, Barbosa JMM. Perfil dos idosos freqüentadores de grupos de convivência em Belo Horizonte, Minas Gerais, Brasil. Cad Saúde Pública. 2008;24(12):2798-808.

23. Gomes R, Nascimento EF, Araújo FC. Por que os homens buscam menos os serviços de saúde que as mulheres? As explicações de homens com baixa escolaridade e com ensino superior. Cad Saúde Pública. 2007;23(3):565-74.

24. Mazo GZ, Mota J, Gonçalves LHT, Matos MG. Nível de atividade física, condições de saúde e características sócio-demográficas de mulheres idosas brasileiras. Rev Port Cien Desp. 2005;5(2):202-12.

25. Matsudo SM, Matsudo VR, Araújo T, Andrade D, Andrade E, Oliveira L, et al. Nível de atividade física da população do estado de São Paulo: análise de acordo com o gênero, idade, nível socioeconômico, distribuição geográfica e de conhecimento. Rev Bras Ci Mov. 2002;10(4):41-50.

26. Conte EMT, Lopez AS. Qualidade de vida e atividade física em mulheres idosas. Revista Brasileira de Ciências do Envelhecimento Humano. 2005;2(1):61-75.

27. Cardoso AS, Levandoski G, Mazo GZ, Prado APM, Cardoso LS. Comparação do nível de atividade física em relação ao gênero de idosos participantes de grupos de convivência. RBCEH. 2008;5(1):9-18.

28. DiPietro L. The epidemiology of physical activity and physical function in older people. Med Sci Sports Exerc. 1996;28(5):596-600.

29. Guimarães LHCT, Galdino DCA, Martins FLM, Vitorino DFM, Pereira KL, Carvalho EM. Comparação da propensão de quedas entre idosos que praticam atividade física e idosos sedentários. Rev. Neurocienc. 2004;12(2):68-72.
30. Ribeiro F, Gomes S, Teixeira F, Brochado G, Oliveira J. Impacto da prática regular de exercício físico no equilíbrio, mobilidade funcional e risco de queda em idosos institucionalizados. Rev Port Cien Desp. 2009;9(1):36-42.

31. Zambaldi PA, Costa TABN, Diniz GCLM, Scalzo PL. Efeito de um treinamento de equilíbrio em um grupo de mulheres idosas da comunidade: estudo piloto de uma abordagem específica, não sistematizada e breve. Acta Fisiatr. 2007;14(1):17-24.

32. Nitz JC, Choy NL. The efficacy of a specific balancestrategy training programme for preventing falls among older people: a pilot randomised controlled trial. Age Ageing. 2004;33(1):52-8.

33. Soares MA, Sacchelli T. Efeitos da cinesioterapia no equilíbrio de idosos. Rev Neurocienc. 2008;16(2): 97-100.

34. Wolf B, Feys H, De Weerdt, van der Meer J, Noom M, Aufdemkampe G, et al. Effect of a physical therapeutic intervention for balance problems in the elderly: a single-blind, randomized, controlled multicentre trial. Clin Rehabil. 2001;15(6):624-36

35. Nascimento LCG, Patrizzi LJ, Oliveira CCES. Efeito de quatro semanas de treinamento proprioceptivo no equilíbrio postural de idosos. Fisioter mov.; 25(2): 325-31.

Received: 02/27/2013

Recebido: 27/02/2013

Approved: 09/25/2013

Aprovado: 25/09/2013 